\title{
Predicted ecological niches and environmental resilience of different formulations of the biocontrol yeast Candida sake CPA-1 using the Bioscreen C
}

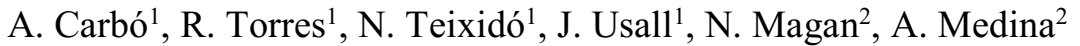

1. IRTA, XaRTA-Postharvest, Edifici Fruitcentre, Parc Científic i Tecnològic Agroalimentari de Lleida, Lleida, Spain

2. Applied Mycology Group, Cranfield Soil and AgriFood Institute, Cranfield University. Cranfield, UK

\begin{abstract}
Environmental resilience of biocontrol microorganisms has been a major bottleneck in the development of effective formulations. Candida sake is an effective biocontrol agent (BCA) against Penicillium expansum, Botrytis cinerea or Rhizopus stolonifer, and different formulations of the BCA have been optimised recently. The objective of this study was to compare the relative tolerance of different dry and liquid formulations of the biocontrol yeast Candida sake CPA-1 to interacting environmental conditions using the Bioscreen C. Initially, the use of this automated turbidimetric method was optimised for use with different formulations of the biocontrol yeast. The best growth curves were obtained for the C. sake CPA-1 strain when grown in a synthetic grape juice medium under continuous shaking and with an initial concentration of $10^{5} \mathrm{CFUs} \mathrm{ml}^{-}$ 1. All the formulations showed a direct relationship between optical density values and yeast concentrations. Temperature $\left(15-30^{\circ} \mathrm{C}\right)$ and water activity $\left(\mathrm{a}_{\mathrm{w}} ; 0.94-0.99\right)$ influenced the yeast resilience most profoundly, whereas the effect of $\mathrm{pH}$ (3-7) was minimal. In general, the liquid formulation grew faster in more interacting environmental conditions but only the yeast cells in the dry potato starch formulation could grow in some stress conditions. This rapid screening method can be used for effective identification of the resilience of different biocontrol formulations under interacting ecological abiotic conditions.
\end{abstract}

Keywords: dehydrated yeast; temperature; stress; ecological niche, interacting environmental conditions, biocontrol; survival; Candida sake 


\section{Introduction}

The development of biocontrol agents (BCAs) has received significant impetus as many crop protection chemical groups have been removed from the EU list of approved compounds for use in agriculture/horticultural crops (European Parliament 2009). This has been partially because of the need to protect the environment and minimise consumer exposure to such chemicals (Droby et al. 2009). Because BCAs are living organisms, their usage and efficacy are strongly dependent on environmental conditions, whereas for chemical products this effect is less significant. The latter products can be applied effectively over a wide range of climatic conditions. A key bottleneck for the use of BCAs in the field has been the narrow relative humidity $(\mathrm{RH})$ and sometimes temperature range for establishment and colonisation of foliar plant parts. Moreover, other unfavourable factors such as UV radiation or rainfall events could limit the development of BCAs under field conditions. Indeed, this has limited the commercial development of BCAs for control of many economically important pre-harvest fungal pathogens (Droby et al. 2016).

In contrast, post-harvest BCAs have been more successful because of the ability to control relative humidity and temperature and the application methods, which include dipping of fruit into formulations of the BCA (Usall et al. 2016). Conditions are conducive for colonisation of the fruit surface by the BCA, as has been demonstrated for C. sake CPA-1 which effectively controlled fungal diseases on pome fruits (Viñas et al. 1998). Indeed, such formulations have also been effective against Botrytis cinerea (Cañamás et al. 2011; Calvo-Garrido et al. 2013a, 2014b) and sour rot in grapes post-harvest (Calvo-Garrido et al. 2013b). Previously, C. sake CPA-1 formulations, both liquid (Abadias et al. 2003; Torres et al. 2003) and solid (Abadias et al. 2001, 2005; Carbó et al. 2017a), have been optimised, especially for post-harvest application, where most of the applications are based on liquid formulations. The environmental stress tolerance of C. sake CPA-1 fresh cells has been studied. For example, Teixidó et al. (1998) studied the ecology of $C$. sake CPA-1 cells in response to water, temperature and $\mathrm{pH}$ stress which helped to identify the boundaries for growth in relation to these factors. However, the behaviour of fresh cells does not represent the real situation when exposed to fluxes in temperature and $\mathrm{RH}$ in the field, especially on phyllosphere surfaces. Some recent studies by Calvo-Garrido et al. (2014b) examined the effect of temperature and $\mathrm{RH}$, and simulated rainfall on the establishment of liquid formulations in vivo on grapes. Survival and efficacy of liquid formulations of CPA-1 was improved by adding a commercial fatty acid-based product called Fungicover ${ }^{\circledR}$ (Cañamás et al. 2011; Calvo-Garrido et al. 2013a, 2014b, a). While studies have previously focused on liquid formulations of this yeast biocontrol agent, very little information is available on dry formulations and their resilience under different interacting environmental conditions.

Recently Carbó et al. (2017b) examined the potential for enhancing the survival and environmental stress tolerance of dry formulations of biocontrol agents for application pre- 
harvest. These were fluidised-bed spray-drying based formulations including biodegradable coatings. This approach may also provide formulations with a wider range of activity against fungal pathogens on different crops. Some authors have suggested that the drying process may result in damage to the cells due to the combined effect of heat and dehydration (Fu and $\mathrm{Chen}$ 2011) and perhaps decrease viability and efficacy of dried BCA formulations under environmental stress fluxes, especially pre-harvest. Thus, tolerance to environmental stress conditions is critical in developing formulations which can maintain their competitiveness and occupation of the desired ecological niche (Magan and Aldred 2008) and exclude the pathogen (Samsudin et al. 2016).

There is thus interest in developing an environmental screening system to facilitate the comparison and identification of formulations of BCAs, which may have the desired ecological resilience, especially for pre-harvest applications. One such approach is the use of the Bioscreen $\mathrm{C}$ system which allows automated turbidimetric measurements of viability and resilience under different interacting abiotic and indeed nutritional factors (Medina et al. 2012; Mohale et al. 2013; Samsudin et al. 2016).

The objectives of the present study were (a) to optimise the Bioscreen C system to evaluate the growth of the BCA yeast $C$. sake CPA-1, (b) to compare the impact of interacting environmental factors of temperature $\left(15-30^{\circ} \mathrm{C}\right), \mathrm{pH}(3-7)$ and water activity $\left(\mathrm{a}_{\mathrm{w}} ; 0.94-0.99\right)$ on the viability and growth of the liquid (Candifruit) commercial formulation and two dry formulations of the BCA C. sake CPA-1 using the optimised turbidimetric method, and (c) to determine the Time To Detection (TTD) for growth of the C. sake CPA-1 formulations under interacting environmental conditions to compare their resilience. All the experiments were carried out with synthetic grape juice as a growth medium to simulate CPA-1 growth on grapes.

\section{Methods}

\subsection{Microbial antagonist}

Strain CPA-1 of C. sake used in the present study was obtained originally from University of Lleida-IRTA, Catalonia, Spain, and it was deposited at the Colección Española de Cultivos Tipo (CECT-10817) at the University of Valencia, Burjassot. C. sake CPA-1 stock cultures were stored in Criobilles tubes (Criobilles AEB 400100, AES Laboratory, Comburg, France) at $-80{ }^{\circ} \mathrm{C}$ for long term storage. When required, CPA-1 cells were sub-cultured on nutrient yeast dextrose agar plates (NYDA: nutrient broth, $8 \mathrm{~g} \mathrm{~L}^{-1}$; yeast extract, $5 \mathrm{~g} \mathrm{~L}^{-1}$; dextrose, $10 \mathrm{~g} \mathrm{~L}^{-1}$; and agar, $15 \mathrm{~g} \mathrm{~L}^{-1}$ ) at $25^{\circ} \mathrm{C}$ for $48 \mathrm{~h}$. After growth, yeast cells were sub-cultured to use or to store at $4{ }^{\circ} \mathrm{C}$ on NYDA plates for a short time. All assays were carried out with three different formulations of the BCA: (i) a liquid formulation registered in Spain under de name Candifruit ${ }^{\mathrm{TM}}$; (ii) a dry formulation based on potato starch; and (iii) a dry formulation based on maltodextrin. Both solid formulations were dried using fluidised-bed spray-drying system by adding biodegradable coatings to enhance the survival 
under stress conditions. The formulation process was done as optimised previously (Carbó et al. 2017b).

Concentration of $C$. sake ( $\mathrm{CFU} \mathrm{m} \mathrm{m}^{-1}$ ) was determined by plating $100 \mu 1$ of serial dilutions on NYDA and incubating at $25{ }^{\circ} \mathrm{C}$ for $48 \mathrm{~h}$. Prior to starting the experiments, the initial viability of formulations was checked by serial dilutions as described previously to calculate the required amount of product to achieve the inoculum size. To carry out the assays, $50 \mathrm{~mL}$ of each formulation was prepared at $10^{7} \mathrm{CFU} \mathrm{ml}{ }^{-1}$ with sterile water, then the required dilution was made to achieve $15 \mathrm{ml}$ of the target concentration of cells. Also $500 \mathrm{mg} \mathrm{l}^{-1}$ of ampicillin were added to each treatment to inhibit any bacterial growth.

\subsection{Turbidimetric assay}

Three Bioscreen C Microbiological Growth Analysers (Labsystems, Helsinky, Findland) were used for the analysis of the turbidity. For all the assays, $200 \mu 1$ of inoculated media were loaded in each well of the non-standard, 100-well microtitre plates. The optical density (OD) was recorded periodically using the $600 \mathrm{~nm}$ filter over the required time for each experiment. The software Easy Bioscreen Experiment (EZExperiment) provided by the manufacturer was used to record all the obtained data. Then, data was exported to a Microsoft ${ }^{\circledR}$ Excel $^{\circledR}$ Professional 2013 (Microsoft Corporation, Redmond, Washington, USA) sheet for further analysis.

\subsection{Culture medium preparation and optimisation}

Synthetic grape juice (SGJ) (Mitchell et al. 2004; Tassou et al. 2009) was used as the base growth medium for C. sake CPA-1 in turbidimetric assays. The medium had the following composition: $\mathrm{D}(+)$ glucose, $70 \mathrm{~g}$; $\mathrm{D}(-)$ fructose, $30 \mathrm{~g}$; $\mathrm{L}(-)$ tartaric acid, $7 \mathrm{~g}$; $\mathrm{L}(-)$ malic acid, $10 \mathrm{~g} ;\left(\mathrm{NH}_{4}\right)_{2} \mathrm{HPO}_{4}$, $0.67 \mathrm{~g} ; \mathrm{KH}_{2} \mathrm{PO}_{4}, 0.67 \mathrm{~g} ; \mathrm{MgSO}_{4} \cdot 7 \mathrm{H}_{2} \mathrm{O}, 1.5 \mathrm{~g} ; \mathrm{NaCl}, 0.15 \mathrm{~g} ; \mathrm{CuCl}_{2}, 0.0015 \mathrm{~g} ; \mathrm{FeSO}_{4} \cdot 7 \mathrm{H}_{2} \mathrm{O}, 0.021$ $\mathrm{g} ; \mathrm{ZnSO}_{4} \cdot 7 \mathrm{H} 2 \mathrm{O}, 0.0075 \mathrm{~g}$; (+) Catechin hydrate, $0.05 \mathrm{~g}$; agar, $25 \mathrm{~g}$; distilled water, $1000 \mathrm{ml}$. The $\mathrm{pH}$ of SGJ was adjusted to 4 with $\mathrm{KOH}\left(2 \mathrm{~mol} \mathrm{~L}^{-1}\right)$.

Three options were tested to optimise the growth media conditions: (i) semi-solid SGJ by adding $0.125 \%$ of agar to liquid SGJ without shaking; (ii) liquid SGJ shaken at medium intensity for 20 sec before every automatic reading; and (iii) liquid media with continuous shaking at medium intensity. The optimisation of the media was carried out with three concentrations of CPA-1: (i) $10^{1} \mathrm{CFU} \mathrm{ml} l^{-1}$; (ii) $10^{3} \mathrm{CFU} \mathrm{ml}^{-1}$; and (iii) $10^{5} \mathrm{CFU} \mathrm{ml}^{-1}$. The Bioscreen $\mathrm{C}$ was run at $25^{\circ} \mathrm{C}$ for 5 days and the $\mathrm{OD}_{600}$ was recorded every $20 \mathrm{~min}$.

\subsection{Selection of an appropriate inoculum size}

The composition of the formulations could cause some turbidity to the medium after inoculation, so it was preferable that the three formulations had a similar initial $\mathrm{OD}_{600}$ value for the turbidimetric assays. For this reason, despite an approximation of the initial cells concentrations was examined previously, a wide range of concentrations from $10^{1} \mathrm{CFU} \mathrm{ml}^{-1}$ to $10^{7} \mathrm{CFU} \mathrm{m}{ }^{-1}$ of CPA-1 was tested to select the appropriate inoculum size. Specifically, $10^{1}, 10^{2}, 10^{3}, 5 \times 10^{3}, 10^{4}$, $5 \times 10^{4}, 10^{5}, 5 \times 10^{5}, 10^{6}, 5 \times 10^{6}$ and $10^{7} \mathrm{CFU} \mathrm{ml}^{-1}$ were tested. 
Three wells of a microtitre plate were used for each inoculum size and in addition $200 \mu 1$ of noninoculated SGJ were loaded into ten wells as a control. The $\mathrm{OD}_{600}$ was recorded every 2 min using the $600 \mathrm{~nm}$ filter for $10 \mathrm{~min}$, and then the average of the recorded values was calculated as the initial turbidity to be compared between the different concentrations. This experiment was conducted at $15{ }^{\circ} \mathrm{C}$ to avoid rapid growth of the yeast and the previously optimised conditions for the medium were used.

\subsection{Correlation between $\mathrm{OD}_{600}$ values and $\mathrm{CPA}-1$ concentrations}

Three CPA-1 solutions containing $10^{5} \mathrm{CFU} \mathrm{m{ } ^ { - 1 }}$ were prepared, one with each formulation. Nonmodified SGJ medium was used and each solution was loaded in a 100 -well microtitre plate. Ten replicates for each condition were used. The $\mathrm{OD}_{600}$ was recorded after inoculation and then after $24 \mathrm{~h}, 45 \mathrm{~h}, 48 \mathrm{~h}$ and $72 \mathrm{~h}$ at $25^{\circ} \mathrm{C}$. At the same times, CFU ml ${ }^{-1}$ was calculated by plating $100 \mu \mathrm{l}$ of serial dilutions on NYDA and incubating at $25{ }^{\circ} \mathrm{C}$ for $48 \mathrm{~h}$. Afterwards, the CFU ml ${ }^{-1}$ were correlated with the $\mathrm{OD}_{600}$ obtained for that well at the tested time.

\subsection{Evaluation of $\boldsymbol{C}$. sake growth under different interacting parameters}

Several interacting conditions of temperature, water activity $\left(\mathrm{a}_{\mathrm{w}}\right)$ and $\mathrm{pH}$ were tested for each formulation with the turbidimetric assays. Specifically, the assays were carried out at four temperatures: (i) $15^{\circ} \mathrm{C}$; (ii) $20^{\circ} \mathrm{C}$; (iii) $25^{\circ} \mathrm{C}$; and (iv) $30^{\circ} \mathrm{C}$; four $\mathrm{a}_{\mathrm{w}}$ : (i) 0.99 ; (ii) 0.98 ; (iii) 0.96 ; and (iv) 0.94; and finally, at three different $\mathrm{pH}$ values; (i) $\mathrm{pH} 3$; (ii) $\mathrm{pH} 5$; and (iii) $\mathrm{pH} 7$.

The $\mathrm{pH}$ of the medium was adjusted with $\mathrm{KOH}\left(2 \mathrm{~mol} \mathrm{~L}^{-1}\right)$ and the $\mathrm{a}_{\mathrm{w}}$ modified by adding different amounts of glycerol $\left(a_{w} 0.99: 2.8 \% \mathrm{w} / \mathrm{v} ; a_{w} 0.98: 9.2 \% \mathrm{w} / \mathrm{v} ; a_{w} 0.96: 18.4 \% \mathrm{w} / \mathrm{v}\right.$; and $a_{w} 0.94$ : $32.2 \% \mathrm{w} / \mathrm{v}$ ). Vials containing $15 \mathrm{ml}$ of the adjusted $\mathrm{pH}$ and $\mathrm{a}_{\mathrm{w}}$ modified media were sterilised for $20 \mathrm{~min}$ at $121^{\circ} \mathrm{C}$. Vials were then shaken and left at room temperature to cool. Afterwards, they were inoculated with the required amount of the concentrated solution of each C. sake formulation and then decanted into the microtitre plates using a multichannel pipette. Ten replicates were used for each treatment, with uninoculated sterile media used as a control. Means of the replicates were only considered if at least 8 of the 10 inoculated wells developed the growth curves. Although, the percentage of wells where $C$. sake CPA-1 achieved to grow was also represented to examine the resilience of the different formulations under the different interacting environmental conditions.

The $\mathrm{OD}_{600}$ was recorded every $20 \mathrm{~min}$ using the $600 \mathrm{~nm}$ filter for at least 7 days, with the total length of the assays depending on the applied stress to the yeast formulation. Before further analyses, the raw datasets were corrected to remove the background signal. The average of the measurements for each well during the first $60 \mathrm{~min}$ was calculated and automatically subtracted from all subsequent measurements in order to remove the different signal backgrounds. The time to detection (TTD) for an $\mathrm{OD}_{600}$ of 0.5 was obtained for all environmental conditions using a Microsoft ${ }^{\circledR}$ Excel $^{\circledR}$ template (kindly provided by Dr. R. Lambert; Samsudin et al. 2016), which used linear interpolation between successive $\mathrm{OD}_{600}$ readings to predict the $\mathrm{TTD}$ at $\mathrm{OD}_{600}=0.5$. 


\subsection{Statistical analyses}

The ability to growth of $C$. sake formulations was analysed using a Generalised Linear Model based on a binomial distribution and logit-link function. Prior the analysis, the response variable TTD 0.5 (days) was transformed to binary data; where 0 values indicated no growth for an $\mathrm{OD}_{600}$ of 0.5 , whereas 1 values indicated that $C$. sake achieved to growth at least until an $\mathrm{OD}_{600}$ of 0.5 . Effects of different environmental stress factors were compared by orthogonal contrasts. All analysis was performed using JMP Pro12 software (SAS Instiute Inc., NC, U.S.A).

\section{Results}

\subsection{Optimisation of the culture medium conditions for subsequent experiments with the} Bioscreen

The growth curves obtained for $C$. sake CPA-1 on the synthetic grape juice (SGJ) medium are compared in Figure 1. This shows that growth of the yeast over time was most consistent with continuous shaking (Fig. 1c). The initial concentration of yeast cells also showed that the reproducibility was better at $10^{5} \mathrm{CFUs}_{\mathrm{mL}^{-1}}$ (Fig. 1d). Other semi-solid media or liquid media with intermittent shaking (every $20 \mathrm{sec}$ before absorbance measurement) did not give well defined and distinct phases for the lag, exponential and stationary phases (Figs. 1a and 1b).

Differences between media conditions were observed at the end of the growth period when the 100-well microtitre plates were visually examined. The yeast cells appeared to be uniformly distributed in the wells containing liquid medium which was continuously shaken. In other conditions, the cells appeared to have been deposited at the bottom of the wells (semi-solid or non-agitated liquid media). The highest tested concentration for which no $\mathrm{OD}_{600}$ differences amongst the formulations was obtained was $10^{5} \mathrm{CFUs} \mathrm{mL}^{-1}$. This coincided with the best results obtained due to the faster cell growth and the good inter-well reproducibility (Fig. 1d).

\subsection{Optimisation of inoculum size}

No differences were observed among formulations when low concentrations of C. sake CPA-1 cells were tested. However, the initial turbidity among the formulations varied from $5 \times 10^{5}$ to $5 \times 10^{6} \mathrm{CFUs} \mathrm{mL}^{-1}$ based on their natural formulated turbidity (Fig. 2).

\subsection{Correlation between $\mathrm{OD}_{600}$ values and $\mathrm{C}$. sake concentrations}

The good correlation between $\mathrm{C}$. sake concentrations and the $\mathrm{OD}_{600}$ readings, when adjusted to using the power trend method, confirmed that the $\mathrm{OD}_{600}$ readings were representative of cell concentrations (Fig. 3). This demonstrated that the three yeast formulations achieved a similar concentration for a specific $\mathrm{OD}_{600}$ value, so that they were comparable. In fact, when an $\mathrm{OD}_{600}$ value of around 1 was obtained, the three formulations achieved a similar concentration; the same occurred with an $\mathrm{OD}_{600}$ value $>1.5$ (Fig. 3). Nevertheless, after reaching an $\mathrm{OD}_{600}$ of 0.5 the power trend line slope decreased, and a higher increase in the $\mathrm{OD}_{600}$ value was required to show an increase in C. sake CPA-1 concentration. 


\subsection{Resilience of $C$. sake CPA-1 formulations under environmental stress}

\subsubsection{Comparison of liquid and dry formulations}

There were significant differences in the ability of the yeast cells in the formulations to grow, including between the two fluidised-bed dried formulations based on the percentage (\%) Log worth weightings for the different factors (Table 1; Fig. 4). Indeed, temperature, $\mathrm{pH}$ and $\mathrm{a}_{\mathrm{w}}$ had differential effects on each of the three formulations (Fig. 4). In general, the $\mathrm{pH}$ appeared to have less impact on the viability of the formulations. Temperature and $a_{w}$ were the main factors influencing the growth of $C$. sake CPA-1 formulations in terms of the relative influence based on the weighting of the factors for each formulation. Interestingly, the liquid formulation (Candifruit) was more sensitive to temperature $(53.8 \%)$, whilst the dried potato starch formulation was predominantly affected by $\mathrm{a}_{\mathrm{w}}(58.8 \%)$. In contrast, temperature (49.7\%) and $\mathrm{a}_{\mathrm{w}}(49.3 \%)$ affected the dried maltodextrin formulation with a similar weighting.

\subsubsection{Effect of temperature}

The viability and growth of the different yeast cell formulations was significantly affected by temperature (Table 2). Overall, 15 and $20^{\circ} \mathrm{C}$ were the optimum temperatures for growth of the yeast formulations. For the liquid formulation (Candifruit) there was a significant influence of each temperature with maximum growth at $20^{\circ} \mathrm{C}$ (Fig. 5). For the dry potato starch-based formulation there were no differences in the temperature range $15-25^{\circ} \mathrm{C}$. For the maltodextrin dry formulation similar optimum growth were observed at 15 and $20^{\circ} \mathrm{C}$. However, at $25^{\circ} \mathrm{C}$ the percentage of inoculated wells where CPA-1 grew was decreased significantly. At $30^{\circ} \mathrm{C}$, yeasts cells in all three formulations had difficulty in becoming established, with only the dry potato starch formulation showing limited viability and growth.

\subsubsection{Effect of water activity $\left(\mathrm{a}_{\mathrm{w}}\right)$}

Fig. 5 shows the effect of water stress on relative growth of the yeast cell formulations. In all cases maximum and rapid growth occurred of all three formulations with relatively freely available water $\left(0.99 \mathrm{a}_{\mathrm{w}}\right)$. Indeed, there was also no significant differences between viability and growth at 0.99 and $0.98 \mathrm{a}_{\mathrm{w}}$ for the liquid Candifruit and dried Maltodextrin formulations. Differences among formulations were only observed under extreme water stress conditions (0.94 and $0.96 \mathrm{a}_{\mathrm{w}}$ ). Indeed, at $0.94 \mathrm{a}_{\mathrm{w}}$ only the liquid Candifruit formulation had the resilience for active growth.

\subsubsection{Effect of $\mathrm{pH}$}

The maximum growth of the yeast formulations was in the synthetic grape juice medium adjusted to $\mathrm{pH}$ levels of 5 and 7 (Fig. 5). However, significant differences were observed between $\mathrm{pH} 5$ and 7 for the liquid Candifruit formulation, which appeared to be better adapted to $\mathrm{pH}$ 5. The poorest viability and growth was at $\mathrm{pH} 3$ for all three tested formulations. No significant differences were observed among formulations at each individual $\mathrm{pH}$ level. 


\subsection{Effect of interacting environmental stresses on the Time To Detection (TTD) for growth}

of the $C$. sake formulations

In general, the liquid Candifruit formulation grew faster in more interacting environmental conditions (Fig. 6). However, only the dry potato starch formulated yeast cells could grow in some temperature stress conditions whereas the liquid Candifruit formulation could not develop at all (Fig. 6).

Overall, all the formulations were able to grow in the interacting conditions of $\mathrm{pH}(3,5$ and 7$)$, temperature $\left(15\right.$ to $\left.25^{\circ} \mathrm{C}\right)$ and $\mathrm{a}_{\mathrm{w}}$ levels of 0.99 to 0.96 . The only exceptions were the liquid Candifruit and the dry maltodextrin formulations which were unable to grow at $\mathrm{pH} 3,25^{\circ} \mathrm{C}$ and $0.96 \mathrm{a}_{\mathrm{w}}$. C. sake development at $30^{\circ} \mathrm{C}$ or $0.94 \mathrm{a}_{\mathrm{w}}$ was significantly restricted due to the high temperature or water stress conditions. In fact, only the dry potato starch formulation could grow at $30^{\circ} \mathrm{C}$ and $\mathrm{pH} 5$ or 7 and $0.99 \mathrm{a}_{\mathrm{w}}$. In contrast, the best resilience at extreme $\mathrm{a}_{\mathrm{w}}$ levels for growth of this yeast $\left(0.94 \mathrm{a}_{\mathrm{w}}\right)$ was restricted to the liquid Candifruit formulation at $\mathrm{pH} 5$ and $20^{\circ} \mathrm{C}$.

All two and three-factor interactions among different environmental conditions ( $\mathrm{pH}$, temperature and $\mathrm{a}_{\mathrm{w}}$ ) were statistically significant $(\mathrm{P}<0.0001)$. As shown in Fig. 4 , temperature and water activity had a high impact on the yeast growth and affected the TTD.

\section{Discussion}

Resilience of different formulations of a biocontrol agent in relation to environmental stress was examined to identify the relative range of conditions and boundaries for effective viability and establishment. This study has shown that there are significant differences between a liquid and two dry formulations in terms of growth and establishment, especially under interacting conditions of $\mathrm{a}_{\mathrm{w}}$, temperature and $\mathrm{pH}$. This environmental screening approach may be beneficial in helping to identify those formulations which may have better viability in the field with conserved biocontrol efficacy. The use of the Bioscreen $\mathrm{C}$ as a rapid automated turbidimetric tool for screening and identifying resilience of different types of formulations could be very beneficial in helping to address this key bottleneck in the development of effective BCA formulations for field use.

Previous studies have highlighted the need to optimise the methodology prior to the development of ecophysiological experiments using the Bioscreen $\mathrm{C}$ with the main parameters including media consistency, shaking and inoculum size (Weiss et al. 2004; Medina et al. 2012). Medina et al. (2012) optimised the semi-solid medium to analyses filamentous fungal growth using the Bioscreen C, whereas Xuan et al. (2017) used liquid media shaken for $20 \mathrm{sec}$ before each measurement for studies with Listeria monocytogenes. Thus, our methodology was optimised to obtain the best results in terms of relative yeast growth: the liquid SGJ medium, which was continuously shaken, with an initial concentration of $10^{5} \mathrm{CFU} \mathrm{mL}{ }^{-1}$ which gave the best growth over time for this biocontrol yeast. Moreover, a direct relationship between $\mathrm{OD}_{600}$ values and yeast concentrations was observed when the three formulations were analysed together. An 
$\mathrm{OD}_{600}$. value of 0.5 was assigned to obtain the TTD in different environmental conditions because changes in $C$ sake CPA-1 concentrations were clear at this value. Previously, an $\mathrm{OD}_{600}$ value of 0.2 was assigned for screening antifungal compounds (Medina et al. 2012) or an $\mathrm{OD}_{600}=0.1$ to calculate the temporal carbon utilisation sequences of Aspergillus flavus strains (Mohale et al. 2013).

Despite the differences in formulation resilience, temperature and $a_{w}$ were the environmental factors that had a major effect on viability and growth of the biocontrol yeast, whereas the impact of $\mathrm{pH}$ was minor. In fact, temperature and $\mathrm{a}_{\mathrm{w}}$ are the two most important stress factors influencing yeast activity, although the host surface $\mathrm{pH}$ may also reduce the growth of the biocontrol agent (Sui et al. 2015). Exposure to heat stress is expected when C. sake CPA-1 is applied pre-harvest to grapes; therefore high temperatures can reduce the viability of the BCA. The $\mathrm{a}_{\mathrm{w}}$ of grapes is about $0.977 \pm 0.001$ (Fernández-Salguero et al. 1993) and their $\mathrm{pH}$ varies from 3.0 to 4.5 (Worobo and Splittstoesser 2005). Assuming that the $a_{w}$ after the BCA application depends on the environmental conditions within the fruit (Sui et al. 2015), the biocontrol yeast cells applied to the surface of grapes will be exposed to microclimatic conditions representing $\mathrm{a}_{\mathrm{w}}$ values $>0.97$ $\mathrm{a}_{\mathrm{w}}$, at least during the ripening stage. When $C$. sake formulations were subjected to these stress conditions ( $\mathrm{pH} 3$ to 4.5 and $\mathrm{a}_{\mathrm{w}}>0.97$ ), both liquid and dry formulations had viable yeast cells which could effectively grow at 15 to $25^{\circ} \mathrm{C}$.

The yeast cells in the liquid formulation (Candifruit) usually developed faster than the dry formulations but differences were less pronounced under environmental stress conditions. For example, at $25^{\circ} \mathrm{C}$ and $0.96 \mathrm{a}_{\mathrm{w}}$ at $\mathrm{pH} 3$ and 7 . The vital functions of microorganisms can often reach a dormant state during the drying process (Berninger et al. 2018) and they only become active again during rehydration (García 2011). This may give liquid formulations an advantage allowing slightly faster recovery and growth when favourable environmental conditions occur. When comparing the TTD (OD of 0.5 ) of both fluidised-bed spray-dried formulations, generally the TTDs for the potato starch formulation was shorter than the TTDs for the the maltodextrin formulation. This suggests that skimmed milk and sucrose incorporated into the maltodextrin formulation improved the viability of cells after the drying process (Carbó et al. 2017b) but these protective compounds do not favour the development of the yeast after rehydration. It may be possible that carbohydrate composition of pregelatinised potato starch could be more favourable than maltodextrin carbohydrate composition for C. sake CPA-1 viability and development, although maltodextrin molecular chains are shorter. Previous studies with nutritional utilisation patterns have shown that depending on the environmental conditions the TTD and the rates of utilisation of C-sources may vary for biocontrol agents and fungal pathogens (Mohale et al., 2013; Samsudin et al., 2016). The TTD could be used effectively as a rapid tool for comparing and identifying promising formulations for targetted applications pre-harvest. 
In general, none of the three studied C. sake formulations could develop in extreme environmental conditions at $0.94 \mathrm{a}_{\mathrm{w}}$, or high temperatures $\left(30-35^{\circ} \mathrm{C}\right)$. The yeast cells in the liquid formulation were able to grow under extreme $\mathrm{a}_{\mathrm{w}}$ conditions at $20^{\circ} \mathrm{C}$ and $\mathrm{pH} 5$. However, under temperature stress, the potato starch formulation was more resilient than the other two tested. Only yeast cells in this fluidised-bed spray-dried formulation which included biodegradable coatings was able to grow at $30^{\circ} \mathrm{C}+$ freely available water $\left(0.99 \mathrm{a}_{\mathrm{w}}\right)$ and $\mathrm{pH} 5$ or 7 . These results support recent studies by Carbó et al. (2017b) where field applications of these three formulations showed that the dry potato starch formulation showed better establishment with the best resilience on grapes surfaces. Interestingly, the efficacy and survival of $C$. sake CPA-1 fresh cells was previously shown to be improved by the addition of coatings in the formulation (Marín et al. 2016). Indeed, these types of coatings have been demonstrated to improve efficacy of other yeast and bacterial BCAs (Aloui et al. 2015; Parafati et al. 2016).

In summary, the optimised environmental screen using the Bioscreen $\mathrm{C}$ enables the rapid comparison of the resilience of different formulations in the target ecological niche. For the three formulations evaluated in the present study, it was demonstrated that the C. sake CPA-1 BCA is effective over a wide range of environmental conditions, with some limitations under extreme environmental stress conditions. Although fluidised-bed spray-dried formulations resulted in some cell damage, they appear to show effective environmental resilience after desiccation. The potato starch formulation was able to extend the ecological niche range, especially tolerance of high temperature, possibly due to the incorporation of biodegradable coatings during the drying process.

\section{Compliance and Ethical Standards}

Conflict of interest: The authors declare that they have no conflict of interest.

\section{References}

Abadias M, Teixidó N, Usall J, et al (2005) Survival of the postharvest biocontrol yeast Candida sake CPA-1 after dehydration by spray-drying. Biocontrol Sci Technol 15:835-846. doi: 10.1080/09583150500187041

Abadias M, Teixidó N, Usall J, et al (2001) Viability, efficacy, and storage stability of freezedried biocontrol agent Candida sake using different protective and rehydration media. J Food Prot 64:856-861

Abadias M, Usall J, Teixidó N, Viñas I (2003) Liquid formulation of the postharvest biocontrol agent Candida sake CPA-1 in isotonic solutions. Phytopathology 93:436-442. doi: 10.1094/PHYTO.2003.93.4.436

Aloui H, Licciardello F, Khwaldia K, et al (2015) Physical properties and antifungal activity of bioactive films containing Wickerhamomyces anomalus killer yeast and their application for preservation of oranges and control of postharvest green mold caused by Penicillium digitatum. Int J Food Microbiol 200:22-30. doi: 10.1016/j.ijfoodmicro.2015.01.015 
Berninger T, González López Ó, Bejarano A, et al (2018) Maintenance and assessment of cell viability in formulation of non-sporulating bacterial inoculants. Microb Biotechnol 11:277301. doi: $10.1111 / 1751-7915.12880$

Calvo-Garrido C, Elmer P, Viñas I, et al (2013a) Biological control of botrytis bunch rot in organic wine grapes with the yeast antagonist Candida sake CPA-1. Plant Pathol 62:510519. doi: 10.1111/j.1365-3059.2012.02684.x

Calvo-Garrido C, Elmer PAG, Parry FJ, et al (2014a) Mode of action of a fatty acid-based natural product to control Botrytis cinerea in grapes. J Appl Microbiol 116:967-979. doi: 10.1111/jam. 12430

Calvo-Garrido C, Teixidó N, Roudet J, et al (2014b) Biological control of Botrytis bunch rot in Atlantic climate vineyards with Candida sake CPA-1 and its survival under limiting conditions of temperature and humidity. Biol Control 79:24-35. doi: 10.1016/j.biocontrol.2014.05.011

Calvo-Garrido C, Viñas I, Elmer P, et al (2013b) Candida sake CPA-1 and other biologically based products as potential control strategies to reduce sour rot of grapes. Lett Appl Microbiol 57:356-361. doi: 10.1111/lam.12121

Cañamás TP, Viñas I, Torres R, et al (2011) Field applications of improved formulations of Candida sake CPA-1 for control of Botrytis cinerea in grapes. Biol Control 56:150-158. doi: 10.1016/j.biocontrol.2010.11.007

Carbó A, Torres R, Usall J, et al (2017a) Dry formulations of the biocontrol agent Candida sake CPA-1 using fluidised bed drying to control the main postharvest diseases on fruits. J Sci Food Agric 97:3691-3698. doi: 10.1002/jsfa.8229

Carbó A, Torres R, Usall J, et al (2017b) Fluidised-bed spray-drying formulations of Candida sake CPA-1 by adding biodegradable coatings to enhance their survival under stress conditions. Appl Microbiol Biotechnol 101:7865-7876. doi: 10.1007/s00253-017-8529-5

Droby S, Wisniewski M, Macarisin D, Wilson C (2009) Twenty years of postharvest biocontrol research: Is it time for a new paradigm? Postharvest Biol Technol 52:137-145. doi: 10.1016/j.postharvbio.2008.11.009

Droby S, Wisniewski M, Teixidó N, et al (2016) The science, development, and commercialization of postharvest biocontrol products. Postharvest Biol Technol 122:4-11. doi: 10.1016/j.postharvbio.2016.04.006

European Parliament (2009) Regulation (EC) No 1107/2009 of the European Parliament and of the Council of 21 October 2009

Fernández-Salguero J, Gómez R, Carmona MA (1993) Water activity in selected high-moisture foods. J Food Compos Anal 6:364-369

$\mathrm{Fu}$ N, Chen XD (2011) Towards a maximal cell survival in convective thermal drying processes. Food Res Int 44:1127-1149. doi: 10.1016/j.foodres.2011.03.053 
García AH (2011) Anhydrobiosis in bacteria: From physiology to applications. J Biosci 36:939950. doi: 10.1007/s12038-011-9107-0

Magan N, Aldred D (2008) Environmental fluxes and fungal interactions: maintaining a competitive edge. In: Avery S V., Stratford M, West P Van (eds) Stress in yeasts and filamentous fungi. Elsevier Inc., Amsterdam, pp 19-35

Marín A, Cháfer M, Atarés L, et al (2016) Effect of different coating-forming agents on the efficacy of the biocontrol agent Candida sake CPA-1 for control of Botrytis cinerea on grapes. Biol Control 96:108-119. doi: 10.1016/j.biocontrol.2016.02.012

Medina A, Lambert RJW, Magan N (2012) Rapid throughput analysis of filamentous fungal growth using turbidimetric measurements with the Bioscreen $\mathrm{C}$ : a tool for screening antifungal compounds. Fungal Biol 116:161-169. doi: 10.1016/j.funbio.2011.11.001

Mitchell D, Parra R, Aldred D, Magan N (2004) Water and temperature relations of growth and ochratoxin A production by Aspergillus carbonarius strains from grapes in Europe and Israel. J Appl Microbiol 97:439-445. doi: 10.1111/j.1365-2672.2004.02321.x

Mohale S, Magan N, Medina A (2013) Comparison of growth, nutritional utilisation patterns, and niche overlap indices of toxigenic and atoxigenic Aspergillus flavus strains. Fungal Biol 117:650-659. doi: 10.1016/j.funbio.2013.07.002

Parafati L, Vitale A, Restuccia C, Cirvilleri G (2016) The effect of locust bean gum (LBG)-based edible coatings carrying biocontrol yeasts against Penicillium digitatum and Penicillium italicum causal agents of postharvest decay of mandarin fruit. Food Microbiol 58:87-94. doi: 10.1016/j.fm.2016.03.014

Samsudin NIP, Medina A, Megan N (2016) Relationship between environmental conditions, carbon utilisation patterns and Niche Overlap Indices of the mycotoxigenic species Fusarium verticillioides and the biocontrol agent Clonostachys rosea. Fungal Ecol 24:4452. doi: 10.1016/j.funeco.2016.05.010

Sui Y, Wisniewski M, Droby S, Liu J (2015) Responses of yeast biocontrol agents to environmental stress. Appl Environ Microbiol 81:2968-2975. doi: 10.1128/AEM.04203-14

Tassou CC, Natskoulis PI, Magan N, Panagou EZ (2009) Effect of temperature and water activity on growth and ochratoxin A production boundaries of two Aspergillus carbonarius isolates on a simulated grape juice medium. J Appl Microbiol 107:257-268. doi: 10.1111/j.13652672.2009.04203.x

Teixidó N, Viñas I, Usall J, et al (1998) Ecophysiological responses of the biocontrol yeast Candida sake to water, temperature and pH stress. J Appl Microbiol 84:192-200. doi: 10.1046/j.1365-2672.1998.00320.x

Torres R, Usall J, Teixidó N, et al (2003) Liquid formulation of the biocontrol agent Candida sake by modifying water activity or adding protectants. J Appl Microbiol 94:330-339. doi: 10.1046/j.1365-2672.2003.01843.x 
Usall J, Torres R, Teixidó N (2016) Biological control of postharvest diseases on fruit: a suitable alternative? Curr Opin Food Sci 11:51-55. doi: 10.1016/j.cofs.2016.09.002

Viñas I, Usall J, Teixidó N, Sanchis V (1998) Biological control of major postharvest pathogens on apple with Candida sake. Int J Food Microbiol 40:9-16. doi: 10.1016/S01681605(98)00009-9

Weiss A, Delproposto J, Giroux CN (2004) High-throughput phenotypic profiling of geneenvironment interactions by quantitative growth curve analysis in Saccharomyces cerevisiae. Anal Biochem 327:23-34. doi: 10.1016/j.ab.2003.12.020

Worobo RW, Splittstoesser DF (2005) Microbiology of Fruit Products. In: Barrett DM, Somogyi L, Ramaswamy H (eds) Processing fruits: Science and Technology, 2nd edn. CRC Press, Florida, pp 261-284

Xuan XT, Ding T, Li J, et al (2017) Estimation of growth parameters of Listeria monocytogenes after sublethal heat and slightly acidic electrolyzed water (SAEW) treatment. Food Control 71:17-25. doi: 10.1016/j.foodcont.2016.06.018

\section{Figures}
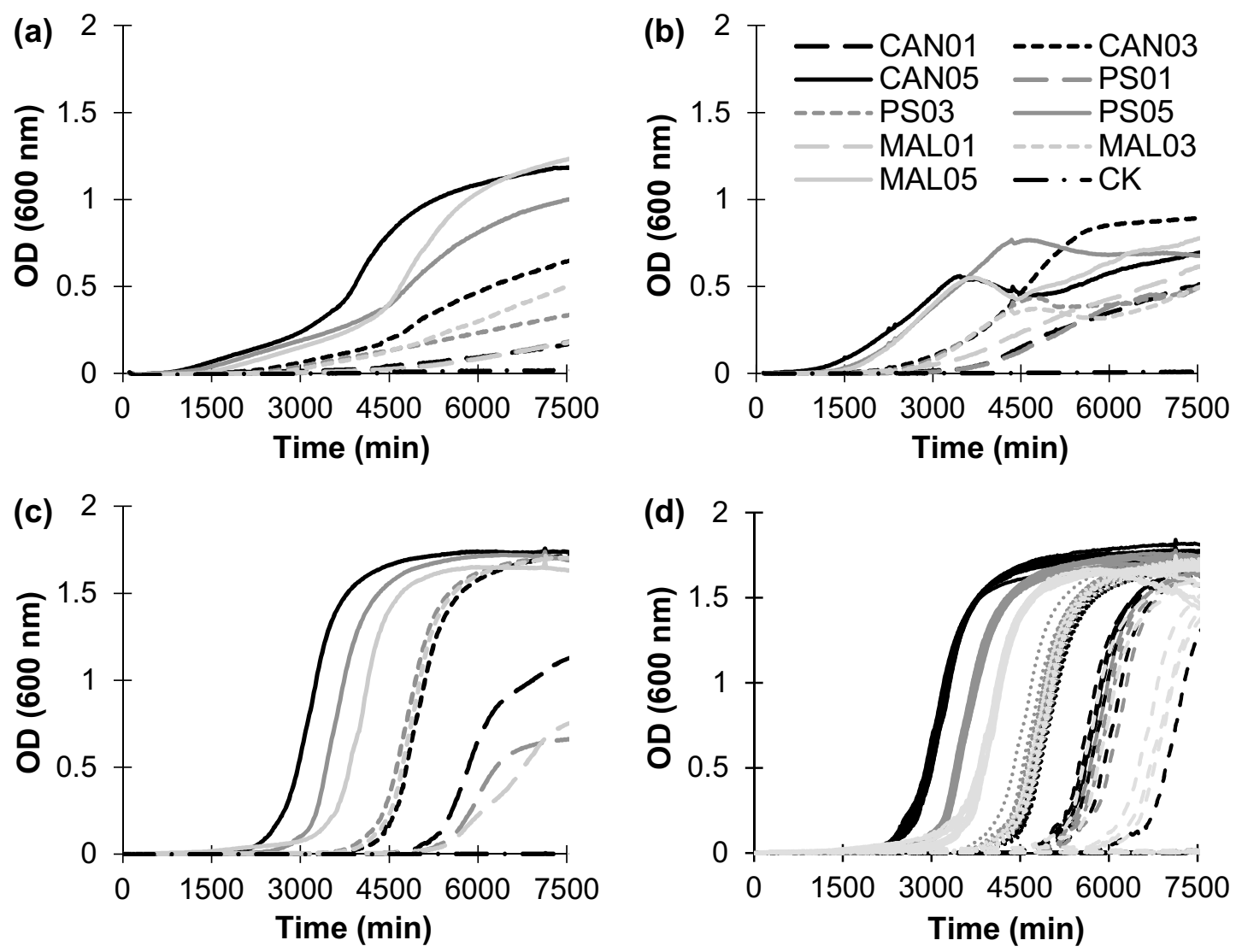
Fig. 1 Growth curves obtained during the optimisation of the synthetic grape juice used as media for C. sake growing in the Bioscreen $\mathrm{C}$ assays: (a) average growth curves (ten individual replicate) obtained with semi-solid media without shaking; (b) average growth curves (ten individual replicates) obtained with liquid media shaken 20 seconds before the automatic reading; (c) average growth curves (ten individual replicates) obtained with liquid media with continuous shaking; and (d) individual curves obtained with liquid media shaken for $20 \mathrm{~s}$ before the automatic reading. Different concentrations of each formulation are represented: Candifruit at $10^{1} \mathrm{CFU} \mathrm{ml}^{-1}$ (CAN01); Candifruit at $10^{3} \mathrm{CFU} \mathrm{m}{ }^{-1}$ (CAN03); Candifruit at $10^{5} \mathrm{CFU} \mathrm{ml}^{-1}$ (CAN05); potato starch formulation at $10^{1} \mathrm{CFU}$ $\mathrm{ml}^{-1}$ (PS01); potato starch formulation at $10^{3} \mathrm{CFU} \mathrm{ml}^{-1}$ (PS03); potato starch formulation at $10^{5} \mathrm{CFU}$ $\mathrm{ml}^{-1}$ (PS05); maltodextrin formulation at $10^{1} \mathrm{CFU} \mathrm{ml}^{-1}$ (MAL01); maltodextrin formulation at $10^{3}$ $\mathrm{CFU} \mathrm{m}{ }^{-1}$ (MAL03); and maltodextrin formulation at $10^{5} \mathrm{CFU} \mathrm{ml}^{-1}$ (MAL05).

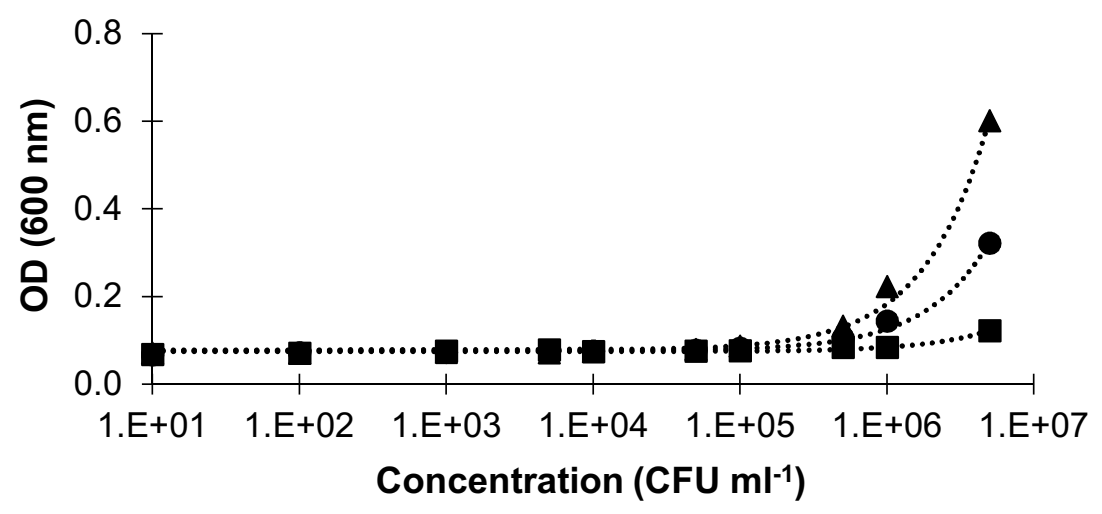

Fig. 2 Initial turbidity values obtained during the optimisation of the inoculum size used in the Bioscreen assays. Three formulations are represented: Candifruit ( $\mathbf{\square})$; potato starch formulation ( $\mathbf{\Delta})$; and maltodextrin formulation $(\bullet)$. Linear trend for each formulation are represented with the dotted lines. Liquid SGJ media with continuous shaking treatment was used. Values are means of 5 readings recorded every 2 min during the first $10 \mathrm{~min}$ after inoculation. Three wells were used for each formulation.

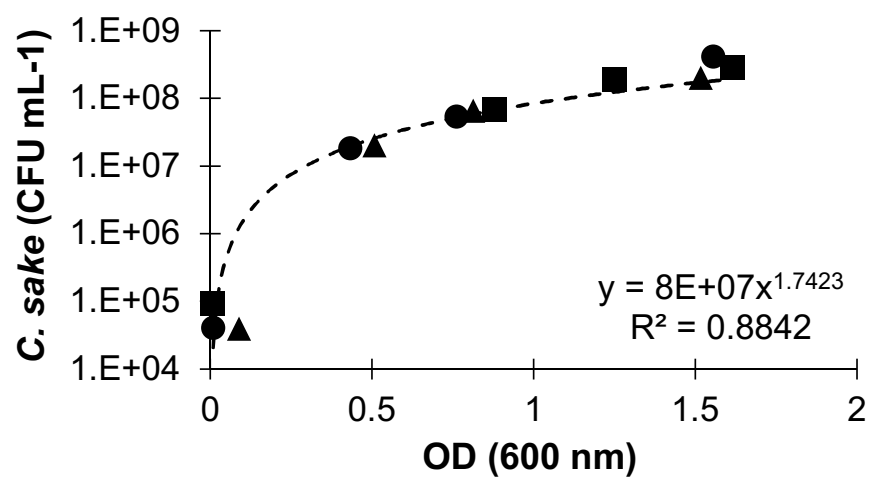


Fig. 3 Correlation between $\mathrm{OD}_{690}$ and C. sake $\left(\mathrm{CFU} \mathrm{ml} l^{-1}\right)$ at different growing times with an initial inoculum size of $10^{5} \mathrm{CFU} \mathrm{ml}{ }^{-1}$. Three formulations are represented: Candifruit (ם); potato starch formulation $(\mathbf{\Delta})$; and maltodextrin formulation $(\bullet)$. The power trend line is represented with the dotted line. Liquid SGJ media with continuous shaking was used.

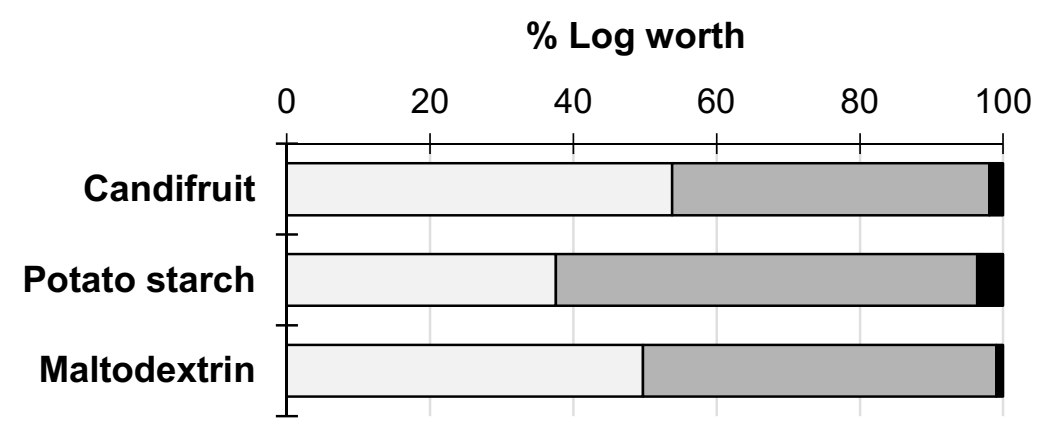

Fig. 4 Summary effect of each tested formulation: Candifruit, potato starch, and maltodextrin. The three studied formulations are represented as LogWorth percentage values to compare the effects in the model: temperature $(\square)$; water activity $(\square)$; and pH (ם).
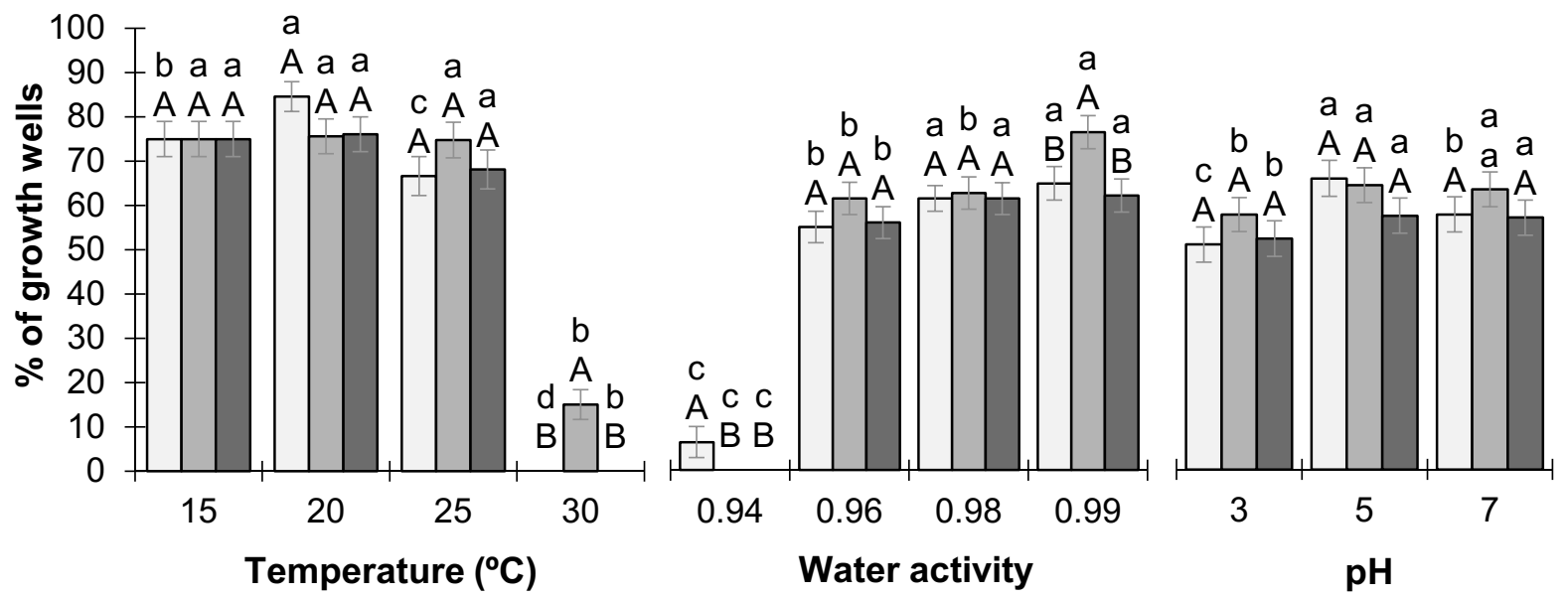

Fig. 5 Graphical representation of the percentage of inoculated wells where C. sake CPA-1 achieved growth for each evaluated condition (temperature, water activity and $\mathrm{pH}$ ). Three formulations are represented in each graph: Candifruit $(\square)$; potato starch formulation ( $\square$ ), and maltodextrin formulation ( $\square$ ). For each treatment and source, percentage values linked by the same letter are not significantly different $(p<0.05)$ according to orthogonal contrasts analysis. Different uppercase letters indicate significant differences between CPA-1 formulations within the same condition (temperature, water activity or $\mathrm{pH}$ ); different lowercase letters indicate significant differences between different evaluated temperature, water activity or $\mathrm{pH}$ conditions within the same formulation. Error bars indicate standard errors of the means. 


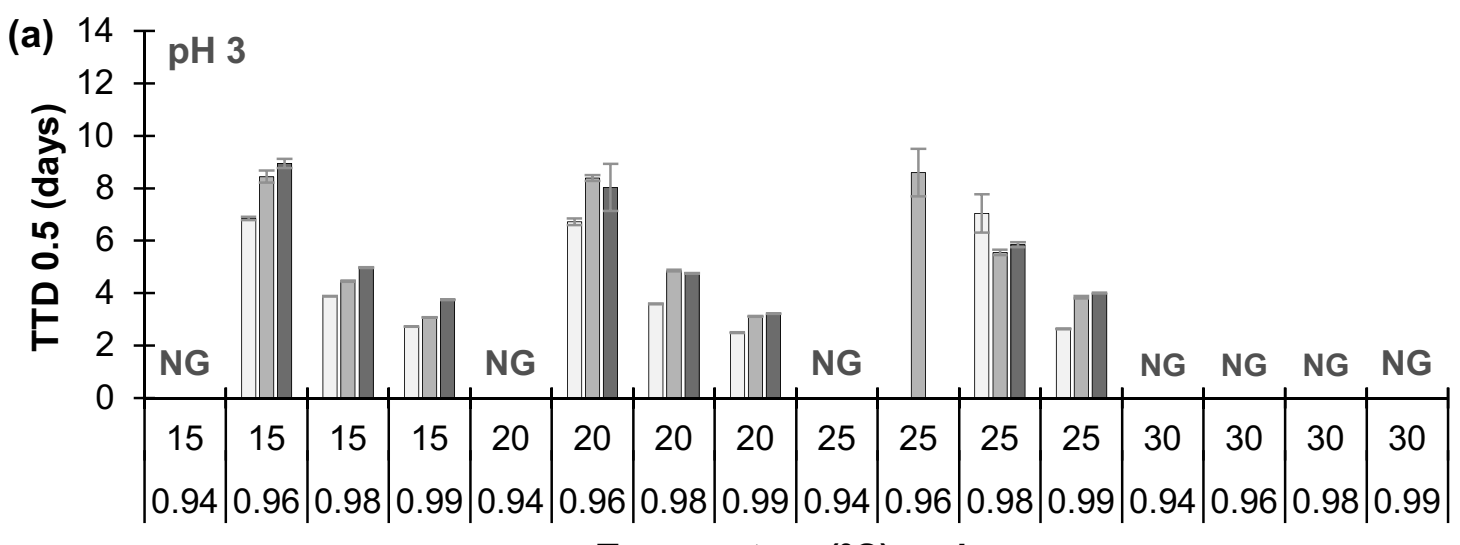

Temperature $\left({ }^{\circ} \mathrm{C}\right)$ and $\mathrm{a}_{\mathrm{w}}$

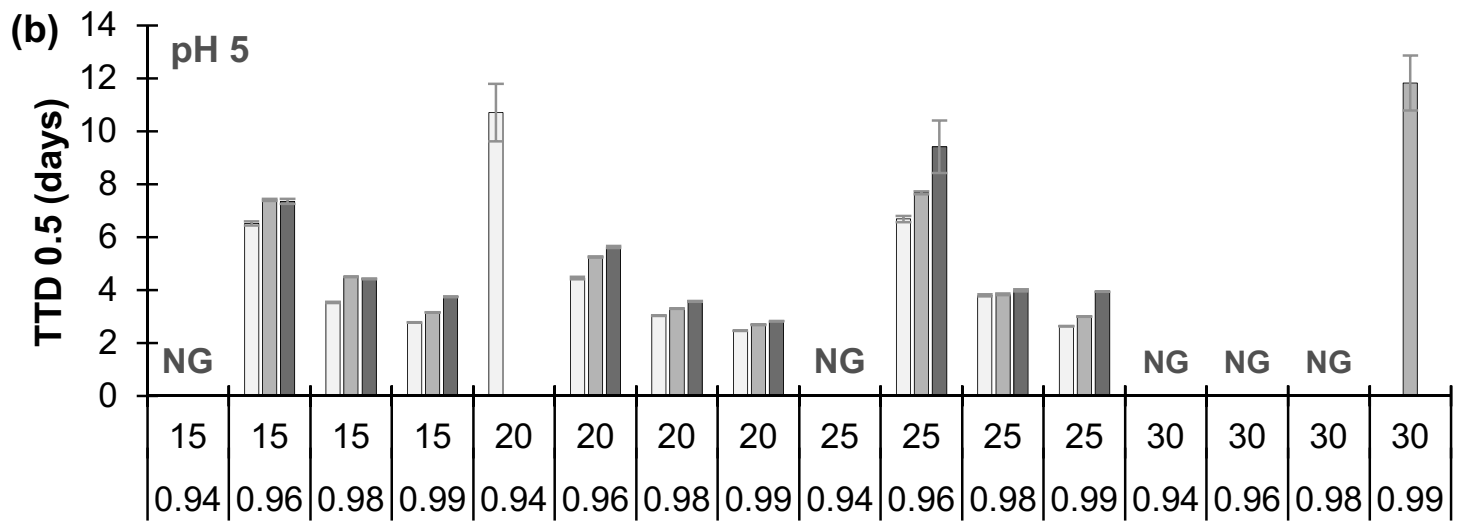

Temperature $\left({ }^{\circ} \mathrm{C}\right)$ and $\mathrm{a}_{\mathrm{w}}$

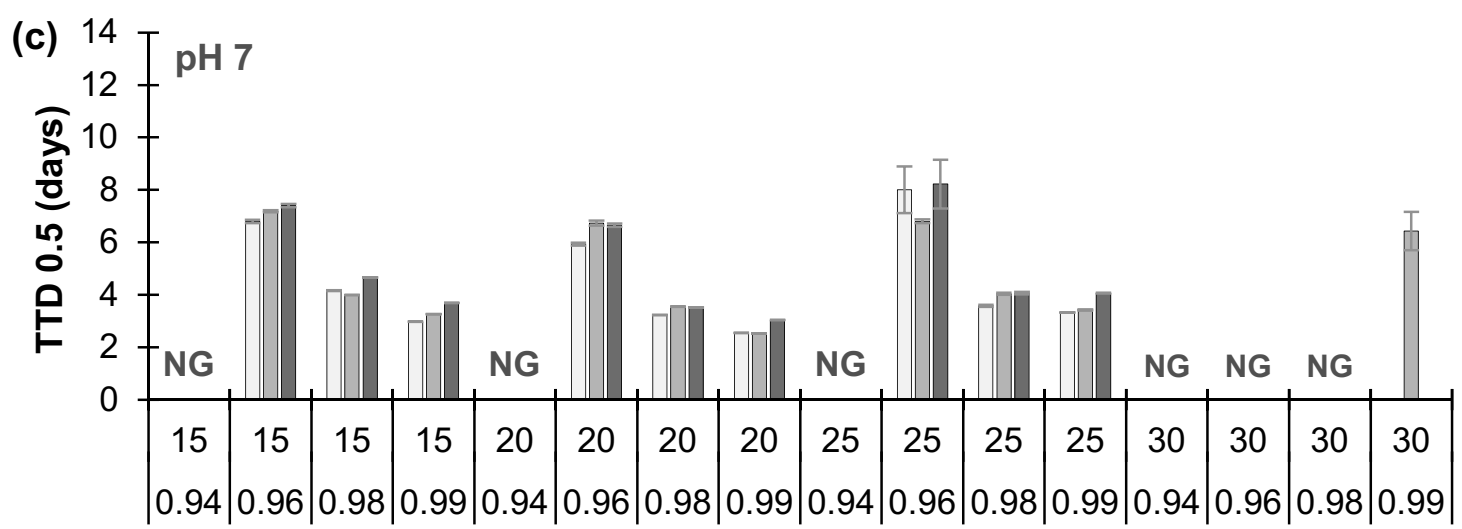

Temperature $\left({ }^{\circ} \mathrm{C}\right)$ and $\mathrm{a}_{\mathrm{w}}$

Fig. 6 Graphical representation of the TTD (0.5) against temperature and water activity at three different $\mathrm{pH}$ : (a) $\mathrm{pH} 3$; (b) $\mathrm{pH}$ 5; and (c) $\mathrm{pH}$ 7. Three formulations are represented in each graph: Candifruit $(\square)$; potato starch formulation $(\square)$, and maltodextrin formulation $(\square)$. Results are the mean of growth curves for ten replicate wells. NG means no growth under those conditions. Error bars indicate standard errors of the means. When bars are not visible, they are smaller than 0.1 days. 